\title{
PENGARUH ATMOSFERIK TERHADAP KEPUASAN DAN NIATAN PERILAKU KONSUMEN
}

\author{
Edi Purwanto \\ Fakultas Ilmu Sosial dan Humaniora, Universitas Bunda Mulia Jakarta \\ epurwanto@bundamulia.ac.id \\ Deny \\ Fakultas Ilmu Sosial dan Humaniora, Universitas Bunda Mulia Jakarta \\ Richa Chandra Tansil \\ Fakultas Ilmu Sosial dan Humaniora, Universitas Bunda Mulia Jakarta
}

\begin{abstract}
We study the atmospheric role at restaurant " $X$ ", a Japanese chain restaurant in numerous Jakarta areas. More specifically, we analyze (1) the effect of atmospherics on service quality; (2) the effect of atmospherics on food quality; (3) the effect of atmospherics on perceived value; (4) the effect of service quality on customer satisfaction; (5) the effect of perceived value on customer satisfaction; (6) the effect of food quality on customer satisfaction; (7) the effect of service quality on behavioral intentions; (8) the effect of customer satisfaction on behavioral intentions; (9) the effect of food quality on behavioral intentions, (10) indirect effect of atmospherics on customer satisfaction; and (11) indirect effect of atmospherics on behavioral intentions. We distributed questionnaires to customers of " $X$ " restaurant and received back 283 questionnaires, of which 229 were usable for further analysis. Overall, the findings support all the hypotheses, except hypotheses (4) and (7), probably because this is a self-service restaurant chain.
\end{abstract}

Keywords: Atmospherics, Service Quality, Perceived Value, Food Quality, Customer Satisfaction, Behavioral Intentions.

\begin{abstract}
ABSTRAK
Penelitian ini dilakukan untuk mengetahui peran atmosferik di restoran "X," sebuah restoran Jepang yang berada di berbagai area di Jakarta. Penelitian ini menganalisis (1) pengaruh atmosferik terhadap kualitas layanan; (2) pengaruh atmosferik terhadap kualitas makanan; (3) pengaruh atmosferik terhadap nilai yang dirasakan; (4) pengaruh kualitas layanan terhadap kepuasan pelanggan; (5) pengaruh nilai yang dirasakan terhadap kepuasan pelanggan; (6) pengaruh kualitas makanan terhadap kepuasan pelanggan; (7) pengaruh kualitas layanan terhadao niatan perilaku konsumen; (8) pengaruh kepuasan pelanggan terhadap niatan perilaku konsumen; (9) pengaruh kualitas makanan terhadap niatan perilaku konsumen; (10) pengaruh tidak langsung atmosferik terhadap kepuasan pelanggan; dan (11) pengaruh tidak langsung atmosferik terhadap niatan perilaku konsumen. Desain penelitian ini adalah kuantitatif. Kami membagikan kuesioner kepada para pelanggan restoran " $X$ " di Jakarta dan kuesioner yang kembali berjumlah 283, yang mana ada 54 kuesioner
\end{abstract}


yang tidak dapat digunakan, sehingga penelitian ini menggunakan 229 sampel. Setiap indikator terbukti sahih dan setiap variabel terbukti handal. Penelitian ini menemukan bahwa pengaruh atmosferik terhadap kualitas layanan, kualitas makanan, dan nilai yang dirakan secara parsial positif dan signifikan. Pengaruh nilai yang dirasakan dan kualitas makanan terhadap kepuasan pelanggan secara parsial juga positif dan signifikan. Pengaruh kepuasan pelanggan terhadap niatan perilaku konsumen positif dan signifikan. Pengaruh kualitas makanan terhadap niatan perilaku konsumen juga ditemukan positif dan signifikan. Pengaruh tidak langsung atmosferik terhadap kepuasan pelanggan dan niatan perilaku konsumen juga positif dan signifikan. Namun, karena di restoran yang diteliti konsumen mereka melayani diri sendiri, maka kualitas layanan tidak berpengaruh signifikan terhadap kepuasan pelanggan dan niatan perilaku konsumen.

Kata kunci: Atmosferik, kualitas layanan, nilai yang dirasakan, kualitas makanan, kepuasan pelanggan, niatan perilaku konsumen.

\section{PENDAHULUAN}

Maraknya pembangunan mall di berbagai tempat dan wilayah di kota-kota besar seperti Jakarta, yang tidak terlewatkan di dalamnya adalah food court yang pada umumnya menjadi bagian sentral dari banyak mall tersebut. Para pengunjung mall pada umumnya ada yang datang dengan tujuan belanja, namun juga ada yang hanya sekedar untuk jalan-jalan dengan keluarga atau teman saja. Yang tidak terlewatkan bagi mereka dalam setiap kunjungan biasanya adalah mampir di food court untuk menikmati makanan. Ada juga yang hanya sekedar minum kopi sambil berbincang-bincang ringan atau pun bincang bisnis dengan rekanan bisnis.

Pada food court area dapat dilihat atmosferik restoran yang memberikan identitas etnik yang menyediakan makanan etnik yang sedang marak dan disenangi oleh para konsumen urban yang lebih kosmopolitan ketimbang etnosentris. Tidak seperti konsumen etnosentris, konsumen kosmopolitan lebih berminat pada produk atau merek luar negeri dan memandang produk dan merek dalam negeri (domestik) lebih rendah kualitasnya dibandingkan dengan produk-produk luar negeri tersebut (Purwanto 2014). Demikian juga halnya dengan produk makanan, apalagi hal tersebut dapat menaikkan gengsi yang dirasakan oleh para konsumen kosmopolitan. Tidak heran banyak bertebaran restoran waralaba asing, misalnya restoran-restoran yang menawarkan makanan Jepang (Japanese foods) atau makanan Korea (Korean foods) dan restoran-restoran siap saji Barat (Western fast-food restaurants) di kotakota besar, khususnya Jakarta. Restoran masakan Jepang seperti Hanamasa, HokaHoka Bento, Keyaki dan masih banyak yang lain dapat ditemukan di berbagai tempat di Jakarta, dan para pengunjungnya kebanyakan adalah orang Indonesia. Hal ini menunjukkan minat yang tinggi dari konsumen kosmopolitan untuk berkunjung dan makan di restoran-rastoran bermerek asing, seperti restoran Jepang, bahkan minat untuk berkunjung berulang-ulang. 
Hal menarik untuk diteliti adalah apakah selain kualitas layanan (service quality), kualitas makanan (food quality) dan nilai yang dirasakan (perceived value), atmosferik restoran (atmospheric) memiliki peran penting dalam menarik pelanggan untuk datang dan merasa puas sehingga akan kembali datang pada kesempatan yang lain? Atmosferik restoran pada umumnya sangat ditonjolkan oleh restoran-restoran bernuansa etnik tersebut. Mulai dari faktor desain termasuk tata letak dan perabotan, musik, warna, aroma dan bahkan seragam pelayanan restoran yang menunjukkan etnik tertentu (misalnya Kimono Jepang) dapat memainkan peran penting dalam menarik pelanggan untuk berkunjung dan makan di restoran tersebut. Penelitian $\mathrm{Ha}$ dan Jang (2012) juga telah membuktikan bagaimana atmosferik restoran menjadi salah satu faktor yang memengaruhi kepuasan pelanggan (customer satisfaction) dan niatan perilaku konsumen (behavioral intentions), selain faktor penting dan umum lainnya, seperti kualitas layanan dan kualitas makanan serta nilai yang dirasakan. Berdasarkan pengamatan terhadap para konsumen kosmopolitan Jakarta yang senang berkunjung dan makan di restoran-restoran asing, penelitian ini dilakukan untuk menguji pengaruh atmosferik terhadap kepuasan pelanggan dan niatan perilaku konsumen yang dimediasi oleh kualitas layanan dan makanan serta nilai yang dirasakan pelanggan pada restoran " $X$ ". Hal yang mendorong pemilihan konsumen restoran " $X$ " sebagai responden atau yang akan diteliti adalah, pertama restoran " $X$ " adalah salah satu restoran Jepang yang cukup terkenal dan masih menarik banyak minat pelanggan di Jakarta hingga saat ini dan kedua, atmosferik masih menjadi daya tarik yang membangkitkan minat pelanggan serta kualitas dari makanannya. Fenomena-fenomena serupa juga terjadi di berbagai tempat di dunia sebagaimana nampak pada penelitian-penelitian terdahulu berikut ini:

Qin dan Prybutok (2008) menemukan pengaruh langsung dan signifikan kualitas layanan dan kepuasan pelanggan terhadap niatan perilaku konsumen di beberapa restoran siap saji (fast-food restaurants). Mereka menemukan bahwa kepuasan pelanggan tidak terbukti menjadi peubah mediasi antara kualitas layanan dan niatan perilaku konsumen karena mereka tidak menemukan pengaruh signifikan kualitas layanan terhadap kepuasan pelanggan. Di sisi lain kualitas makanan berpengaruh secara signifikan terhadap kepuasan pelanggan, demikian juga halnya dengan harga/nilai (price/value). Sehingga dapat dikatakan bahwa kualitas makanan dan harga/nilai memiliki pengaruh signifikan terhadap niatan perilaku konsumen dengan dimediasi oleh peubah kepuasan pelanggan Wen et al. (2012) menguji pengaruh budaya individualistik orang Amerika dan budaya kolektivistik orang China terhadap interrelasi kualitas layanan, kualitas makanan, nilai yang dirasakan, kepuasan pelanggan, dan niatan perilaku konsumen di industri makanan siap saji. Mereka menguji bagaimana budaya nasional sebagai moderator sangat berpengaruh pada hubungan peubah-peubah tersebut. Dengan mengambil sampel dari dua negara, yaitu Amerika Serikat dan China, hasil penelitian ini mengindikasikan bahwa budaya nasional memiliki dampak moderasi pada hubungan tersebut dan ada perbedaan dalam niatan perilaku konsumen antara pelanggan orang Amerika dan orang China. 
Bagi pelanggan Amerika, kualitas layanan dan kualitas makanan memiliki pengaruh yang lebih kuat pada kepuasan pelanggan dari pada bagi pelanggan China. Namun pengaruh nilai yang dirasakan pada kepuasan pelanggan dan pengaruh kepuasan pelanggan terhadap niatan perilaku konsumen lebih kuat di China ketimbang di Amerika Serikat. Jadi temuan penelitian tersebut menunjukkan bahwa kualitas layanan dan nilai yang dirasakan memiliki pengaruh positif dan signifikan terhadap kepuasan pelanggan. Kualitas makanan memiliki pengaruh positif secara langsung dan signifikan terhadap kepuasan pelanggan, dan kepuasan pelanggan berpengaruh positif dan signifikan terhadap niatan perilaku konsumen.

Ha dan Jang (2012) melakukan penelitian dengan mengambil sampel sebanyak 607 responden yang terdiri dari laki-laki dan perempuan dengan perbandingan persentase sebesar $44,8 \%$ dan 55,2\%. Teknik pengambilan sampel dilakukan melalui survei berbasis web yang bergantung pada daya ingat responden mengenai restoran etnik Korea yang pernah dikunjungi oleh responden. Penelitian tersebut adalah untuk mengukur persepsi atmosferik sebuah restoran dengan gaya desain etnik tertentu yang memengaruhi persepsi konsumen mengenai kualitas layanan dan kualitas makanan dan kemudian mengukur bagaimana pengaruh masingmasing dari ketiga peubah tersebut terhadap niatan perilaku konsumen yang berkunjung ke restoran tersebut. Dari penelitian yang mereka lakukan, ditemukan bahwa ada pengaruh signifikan persepsi atmosferik restoran terhadap kualitas layanan. Ditemukan juga bahwa pengaruh persepsi atmosferik terhadap kualitas makanan adalah positif dan signifikan. Pengaruh persepsi atmosferik terhadap niatan perilaku konsumen juga terbukti positif dan signifikan. Kualitas layanan juga berpengaruh positif dan signifikansi terhadap niatan perilaku konsumen, dan ada pengaruh positif dan signifikan kualitas makanan terhadap niatan perilaku konsumen. Pengaruh atmosferik terhadap niatan perilaku konsumen yang dimediasi oleh kualitas layanan maupun kualitas makanan ditemukan positif dan signifikan.

Model konseptual ini merupakan integrasi model konseptual Ha dan Jang (2012), Qin dan Prybutok (2008) dan Wen et al. (2012). Ha dan Jang (2012) menguji model konseptual pengaruh atmosferik terhadap niatan perilaku konsumen yang dimediasi oleh kualitas layanan dan kualitas makanan. Qin dan Prybutok (2008) menguji model konseptual pengaruh kualitas layanan, kualitas makanan dan nilai yang dirasakan terhadap niatan perilaku konsumen yang dimediasi oleh kepuasan pelanggan. Wen et al. (2012) menguji model konseptual pengaruh nilai yang dirasakan, kualitas layanan dan kualitas makanan terhadap niatan perilaku konsumen yang dimediasi oleh kepuasan pelanggan. Penelitian ini menguji pengaruh atmosferik terhadap kepuasan dan niatan perilaku konsumen pada restoran " $\mathrm{X}$ " dengan mediasi kualitas layanan, nilai yang dirasakan dan kualitas produk. 


\section{KAJIAN PUSTAKA DAN PERUMUSAN HIPOTESIS}

\section{Atmosferik}

Menurut Ha dan Jang (2012) lingkungan fisik atau "atmospherics" adalah subyek yang penting untuk menarik para pelanggan restoran datang dan untuk menikmati makan.Adapun yang menjadi dimensi atmosferik tersebut di antaranya adalah faktor-faktor lingkungan, faktor-faktor desain dan faktor-faktor sosial (Baker, Levy, \& Grewal 1992; Ryu \& Jang 2008). Ha dan Jang (2012) menjelaskan bahwa faktor-faktor lingkungan termasuk di dalamnya adalah suasana yang tenang, aroma, warna dan musik. Sementara yang termasuk faktor-faktor desain di antaranya adalah tata letak, perabotan, dan komposisi dinding restoran. Tipe pelanggan, penampilan karyawan, dan keramaian adalah termasuk dalam faktor sosial (Baker, 1992; Ha \& Jang, 2012; Ryu \& Jang, 2008).

\section{Kualitas Layanan}

Menurut Wen et al. (2012) konsep tentang kualitas layanan memainkan peranan yang sangat penting untuk memahami bagaimana mempertahankan kompetitif inti (core competitiveness) dan meningkatkan kinerja bisnis. Persepsi pelanggan tentang kualitas layanan adalah sangat penting bagi organisasi internasional karena itu rentan terhadap variasi budaya, sehingga banyak perusahaan dipaksa untuk menilai dan meningkatkan kualitas layanan mereka secara terusmenerus dalam usaha untuk menarik para pelanggan mereka (Gilbert, Veloutsou, Goode, \& Moutinho, 2006). Menurut Ha dan Jang (2012) kualitas layanan dalam bidang pemasaran jasa termasuk di dalamnya adalah jasa layanan restoran. Layanan di restoran mengandalkan interaksi antara para pelanggan dengan penyedia layanan restoran, yang memengaruhi evaluasi pelanggan tentang layanan selama pengalaman makan mereka.

\section{Kualitas Makanan}

Ferree (1973) mengatakan bahwa kualitas makanan mencakup semua keunggulan yang membuat makanan tersebut dapat diterima dan diminati oleh pembeli makanan tersebut. Wen et al. (2012) memasukkan kualitas makanan sebagai konstruk tersendiri ketimbang menjadikannya dimensi dari kualitas layanan. Menurut Ha dan Jang (2012) kualitas makanan telah diakui sebagai komponen substansial yang dapat menarik pelanggan untuk memilih berkunjung dan makan di restoran tertentu dan merupakan elemen yang memengaruhi loyalitas pelanggan.

\section{Nilai yang dirasakan}

Menurut Zeithaml (1988) nilai yang dirasakan oleh pelangan mengacu pada nilai keseluruhan yang dirasakan oleh pelanggan terhadap suatu produk yang didasarkan pada persepsi apa yang diterima dibandingkan dengan apa yang telah ia keluarkan atau bayarkan (Zeithaml, 1988). Monroe (2002) mendefinisikan nilai yang dirasakan sebagai persepsi pembeli terhadap nilai yang merepresensikan tradeoff 
antara kualitas dan manfaat yang mereka rasakan, kepuasan mereka setara dengan pengorbanan mereka, yaitu harga yang mereka bayarkan untuk suatu produk atau makanan (Chen \& Hsieh 2011).

\section{Kepuasan Pelanggan}

Kata satisfaction (kepuasan) adalah sebuah kata dalam bahasa Inggris yang berasal dari dua gabungan dua kata Latin "satis" yang berarti "cukup baik, memadai", dan "facio" yang berarti "melakukan dan membuat," sehingga kepuasan dapat diartikan sebagai "upaya pemenuhan sesuatu" atau "membuat sesuatu memadai" (Tjiptono \& Chandra 2011). Tjiptono dan Chandra (2011) mengatakan bahwa semua orang memahami apa itu kepuasan, namun begitu diminta untuk mendefinisikannya, kelihatannya tak seorang pun tahu. Hal tersebut dikarenakan ketika istilah kepuasan dihubungkan dengan konteks manajemen dan perilaku konsumen, istilah tersebut menjadi kompleks. Sehingga, menurut Tjiptono dan Chandra (2011) ada 20 definisi yang diacu dalam riset kepuasan pelanggan selama periode 30 tahun. Dari 20 definisi tersebut terdapat kesamaan sehingga dapat disimpulkan ke dalam tiga komponen utama, yaitu (1) kepuasan pelanggan merupakan respon (emosional dan kognitif); (2) respon tersebut menyangkut fokus tertentu (ekspektasi, produk, pengalaman konsumsi, dan seterusnya); dan (3) respon terjadi pada waktu tertentu (setelah konsumsi, setelah pemilihan produk/jasa, berdasarkan pengalaman akumulatif, dan lain-lain (Tjiptono \& Chandra 2011).

\section{Niatan Perilaku Konsumen}

Menurut Zeithaml, Berry dan Parasuraman (1996) konsekuensi persepsi kualitas layanan pada niatan perilaku konsumen pada tingat individu dapat dipandang sebagai sinyal keberhasilan atau kegagalan perusahaan untuk mempertahankan konsumennya atau apakah konsumen akan kembali atau meninggalkan produk atau jasa tertentu. Niatan perilaku konsumen dapat dipandang sebagai indikator yang menandai apakah masih akan setia atau meninggalkan produk atau jasa perusahaan. Parasuraman, Zeithaml dan Berry (1988) lebih lanjut menyatakan bahwa niatan perilaku konsumen dapat dibagi ke dalam tiga dimensi, yaitu recommendation (merekomendasikan produk atau jasa yang pernah dibelinya kepada orang lain), repurchase intention (berniat untuk kembali membeli produk atau jasa tersebut), dan pay more (ia akan tetap membeli meski harganya naik sekalipun).

\section{Pengaruh Atmosferik terhadap Kualitas Layanan}

Menurut Ha dan Jang (2012) atmosferik memiliki pengaruh utama terhadap kualitas dalam konteks layanan dan komponen-komponen lingkungan dalam konteks layanan dapat membantu para pelanggan untuk menilai kualitas layanan. Kemudian dalam penelitiannya Ha dan Jang (2012) menemukan bahwa ada hubungan antara persepsi terhadap atmosferik dan kualitas layanan. Hasil penelitian Ha dan Jang (2012) menemukan bahwa para pelanggan yang memiliki persepsi atmosferik yang 
lebih tinggi secara positif lebih merasakan kualitas layanan. Berdasarkan temuan terdahulu tersebut dapat dibuat hipotesis penelitian pertama seperti berikut ini:

H1: Atmosferik memiliki pengaruh positif dan signifikan terhadap kualitas layanan.

\section{Pengaruh Atmosferik terhadap Kualitas Makanan}

Ha dan Jang (2012) mengatakan bahwa lingkungan fisik mempengaruhi persepsi pelanggan terhadap kualitas produk atau jasa dalam situasi konsumsi. Kemudian penelitian mereka membuktikan bahwa persepsi tentang atmosferik juga menjadi prediktor penting untuk persepsi pelanggan tentang kualitas makanan. Mereka menjelaskan bahwa temuan mereka menegaskan bahwa lingkungan yang lebih baik akan membantu para pelanggan untuk menilai kualitas layanan dan kualitas makanan lebih positif. Berdasarkan temuan penelitian terdahulu tersebut dapat dibuat hipotesis penelitian kedua seperti berikut ini:

H2: Atmosferik memiliki pengaruh positif dan signifikan terhadap kualitas makanan.

\section{Pengaruh Atmosferik terhadap Nilai yang Dirasakan}

Menurut Babin dan Attaway (2000) faktor-faktor lingkungan fisik toko atau atmosferik dapat memengaruhi perasaan subyektif yang dialami oleh para pelanggan di toko tersebut dan hal tersebut memengaruhi nilai berbelanja (shopping value). Tentu saja hal tersebut juga berlaku bagi lingkungan fisik atau atmosferik restoran. Baker, Parasuraman, Grewal dan Voss (2002) menemukan hubungan antara persepsi desain toko dan persepsi tentang harga atau uang yang harus dibayarkan. Oleh sebab itu, Ullakonoja (2011) mengatakan bahwa elemen-elemen desain toko memengaruhi persepsi yang para pelanggan miliki tentang tingkat harga yang diberlakukan oleh toko tersebut. Ahtola (1985) menemukan bahwa diperkirakan sekitar 50\% pelanggan membeli tanpa rencana membeli sebelumnya, sehingga dengan daya tarik atmosferik mudah bagi pelanggan untuk mampir dan menikmati layanan yang diberikan oleh restoran. Para pelanggan yang semula hanya bertujuan untuk jalan-jalan di mall, tanpa berencana untuk melakukan pembelian apapun, sering tertarik dengan atmosferik restoran tertentu dan ingin mencoba makanannya. Dari atmosferik yang menarik dan terkesan mewah, bahkan sebelum masuk restoran tersebut, bisa jadi pelanggan sudah dapat memperkirakan harga dari makanan di restoran tersebut. Ahtola (1985) menemukan bahwa alasan yang meningkatkan nilai yang dirasakan pelanggan adalah atmosferik toko atau restoran. Berdasarkan temuan penelitian terdahulu tersebut dapat dibuat hipotesis penelitian ketiga seperti berikut ini:

H3: Atmosferik memiliki pengaruh positif dan signifikan terhadap nilai yang dirasakan. 


\section{Pengaruh Kualitas Layanan terhadap Kepuasan Pelanggan}

Menurut Ehigie (2006) kepuasan pelanggan dipercaya dipengaruhi oleh beberapa peubah, yang termasuk di dalamnya adalah persepsi dan ekspektasi kualitas layanan (Patterson, Johnson, \& Spreng, 1997; Szymanski \& Henard, 2001; Ehigie, 2006:497). Olorunniwo, Hsu dan Udo (2006) menemukan bahwa kualitas layanan memiliki pengaruh positif dan signifikan terhadap kepuasan pelanggan. Kobylanski et al., (2012) juga menemukan bahwa kualitas layanan memiliki pengaruh positif dan signifikan terhadap kepuasan pelanggan. Polyorat et al., (2010) juga menemukan bahwa kualitas layanan memiliki pengaruh positif dan signifikan terhadap kepuasan pelanggan. Caruana (2002) juga menemukan pengaruh positif dan signifikan kualitas layanan terhadap kepuasan pelanggan. Berdasarkan temuan penelitian terdahulu tersebut dapat dibuat hipotesis penelitian keempat seperti berikut ini.

H4: Kualitas layanan memiliki pengaruh positif dan signifikan terhadap kepuasan pelanggan.

\section{Pengaruh Nilai yang Dirasakan terhadap Kepuasan Pelanggan}

Choi dan Kim (2013) menemukan bahwa kepuasan pelanggan meningkat seiring dengan persepsi nilai fungsional, emosional dan sosial. Menurut Choi dan Kim (2013) para pelanggan akan mempertimbangkan nilai sosial dan emosional sebagai faktor penting bagi kepuasan pelanggan. Cronin, Brady dan Hult (2000) juga menemukan bahwa nilai yang dirasakan memiliki pengaruh penting dan signifikan terhadap kepuasan pelanggan dan kepuasan pelanggan kemudian mempengaruhi niatan perilaku konsumen. Wen et al. (2012) juga menemukan bahwa nilai yang dirasakan memiliki pengaruh signifikan terhadap kepuasan pelanggan. Berdasarkan temuan penelitian terdahulu tersebut dapat dibuat hipotesis penelitian kelima seperti berikut ini:

H5: Nilai yang dirasakan memiliki pengaruh positif dan signifikan terhadap kepuasan pelanggan.

\section{Pengaruh Kualitas Makanan terhadap Kepuasan Pelanggan}

Wen et al. (2012) menemukan bahwa kualitas makanan memiliki pengaruh langsung dan positif terhadap kepuasan pelanggan. Qin et al. (2008) memasukkan kualitas makanan sebagai konstruk terpisah dari dimensi kualitas layanan dan menciptakan hipotesis bahwa kualitas makanan secara langsung dan positif berpengaruh terhadap kepuasan pelanggan. Hipotesis tersebut terbukti bahwa kualitas makanan secara langsung dan positif berpengaruh terhadap kepuasan pelanggan. Berdasarkan temuan penelitian terdahulu tersebut dapat dibuat hipotesis penelitian keenam seperti berikut ini:

H6: Kualitas makanan memiliki pengaruh positif dan signifikan terhadap kepuasan pelanggan. 


\section{Pengaruh Kualitas Layanan terhadap Niatan Perilaku Konsumen}

Siddiqi (2011) menjelaskan bahwa kebanyakan peneliti telah menemukan bahwa kepuasan pelanggan merupakan prediktor dari loyalitas pelanggan. Parasuraman et al. (1988) dan Boulding et al. (1993) seperti dalam Ha dan Jang (2012) telah mengidentifikasi hubungan positif antara kualitas yang dirasakan dan niatan perilaku konsumen, yaitu minat untuk membeli kembali. Pelanggan memberikan kesan positif yang disebarkan dari mulut ke mulut, dan dengan sukarela merekomendasikan kepada orang lain. Kemudian Ha dan Jang (2012) menemukan adanya pengaruh positif dan signifikan kualitas layanan terhadap niatan perilaku konsumen. Berdasarkan temuan terdahulu tersebut dapat dibuat hipotesis penelitian ketujuh seperti berikut ini:

H7: Kualitas layanan memiliki pengaruh positif dan signifikan terhadap niatan perilaku konsumen.

\section{Pengaruh Kepuasan Pelanggan terhadap Niatan Perilaku Konsumen}

Wen et al. (2012) menemukan pengaruh signifikan kepuasan pelanggan terhadap niatan perilaku konsumen. Ehigie (2006) menemukan bahwa persepsi terhadap kualitas layanan dan kepuasan merupakan prediktor signifikan untuk loyalitas pelanggan, yang mana kepuasan pelanggan berkontribusi lebih besar terhadap loyalitas pelanggan. Menurut Ehigie (2006) hipotesis tersebut mendukung literatur lain yang menunjukkan bahwa kepuasan pelanggan merupakan faktor yang menentukan bagi loyalitas. Berdasarkan temuan penelitian terdahulu tersebut dapat dibuat hipotesis penelitian kedelapan seperti berikut ini:

H8: Kepuasan pelanggan memiliki pengaruh positif dan signifikan terhadap niatan perilaku konsumen.

\section{Pengaruh Kualitas Makanan terhadap Niatan Perilaku Konsumen}

Menurut Clark dan Wood (1998) kualitas makanan dan variasi makanan merupakan faktor yang paling berpengaruh terhadap loyalitas pelanggan. Namkung dan Jang (2007) menemukan hubungan positif antara kualitas makanan dan niatan perilaku konsumen. Ha dan Jang (2012) juga menemukan bahwa kualitas layanan merupakan faktor signifikan yang secara positif mempengaruhi niatan perilaku

konsumen. Berdasarkan temuan penelitian terdahulu tersebut dapat dibuat hipotesis penelitian kesembilan seperti berikut ini:

H9: Kualitas makanan memiliki pengaruh positif dan signifikan terhadap niatan perilaku konsumen.

Setelah mengonstruksi peubah-peubah di atas ke dalam proposisi-proposisi, maka proposisi-proposisi tersebut kemudian membentuk model konseptual yang menjadi dasar teoritis penelitian ini. Model konseptual ini dapat dilihat seperti pada Gambar 1. 


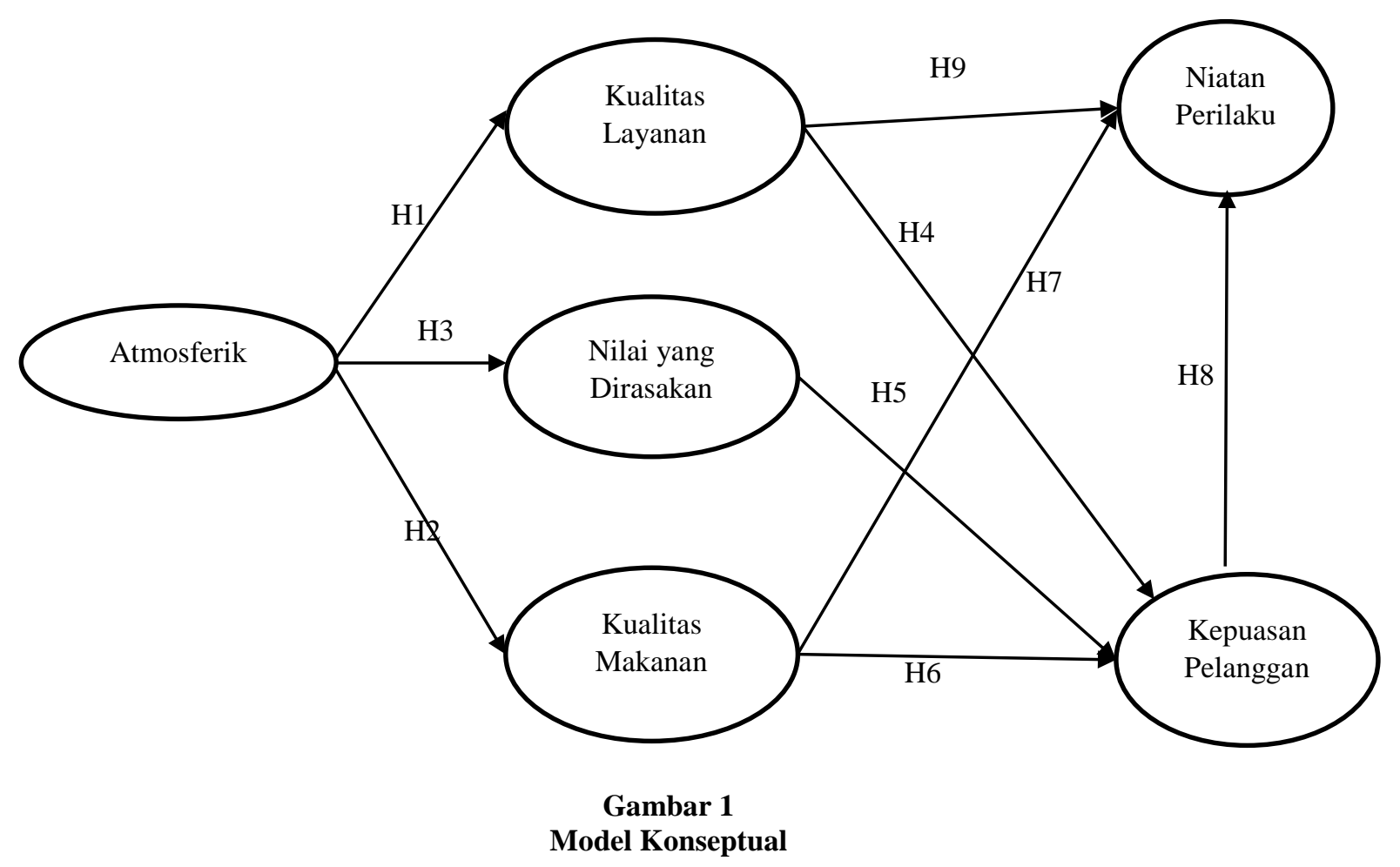

\section{METODA PENELITIAN}

\section{Populasi dan Sampel Penelitian}

Desain penelitian ini adalah kuantitatif dengan membagikan kuesioner kepada sejumlah konsumen restoran " $X$ " di Jakarta dan kuesioner yang kembali dan terisi sebesar 283 kuesioner, namun 54 kuesioner tidak dapat digunakan.Sehinga riset ini menggunakan 229 sampel dari para konsumen restoran tersebut. Restoran "X" adalah restoran masakan Jepang yang dapat ditemukan di berbagai wilayah di Jakarta. Para responden adalah orang-orang yang pernah makan dan tertarik untuk kembali datang dan makan di restoran tersebut. Teknik pengambilan sampel nonprobability sampling, yaitu convenience sampling dengan populasinya adalah para konsumen yang pernah datang dan makan di restoran-restoran " $X$ " di Jakarta dan berencana untuk kembali makan di sana.

\section{Instrumen Penelitian}

Untuk mengukur validitas dan reliabilitas dari setiap peubah dan untuk membandingkan dengan hasil-hasil penelitian sebelumnya, maka semua peubah diukur dengan instrumen yang telah dikembangkan dan digunakan sebelumnya. Peubah Atmosferik, Kualitas Layanan, Kualitas Makanan, dan Niatan Perilaku Konsumen diukur dengan menggunakan skala pengukuran (measurement scales) yang dikembangkan oleh Ha dan Jang (2012). Peubah Nilai yang Dirasakan dan Kepuasan Pelanggan diukur dengan skala pengukuran yang dikembangkan oleh Wen et al. (2012). Para responden diminta untuk memilih tingkat persetujuan mereka 
dengan menggunakan skala Likert-7 poin, mulai dari sangat tidak setuju sampai sangat setuju.

\section{Uji Model}

Dua langkah pendekatan structural equation modeling diterapkan dalam penelitian ini, yaitu pertama mengukur hasil uji outer model, dan kemudian mengukur inner model-nya. Outer model atau model pengukuran menguji hubungan antara peubah laten dengan indikatornya, atau mengukur seberapa jauh indikatorindikator dapat menjelaskan peubah latennya. Indikator refleksif diuji dengan convergent validity, discriminant validity atau dengan average variance extracted $(A V E)$, dan dengan composite reliability. Sedangkan indikator formatif diuji berdasarkan substantive content-nya dengan membandingkan besarnya relative weight dan melihat signifikansinya. Untuk convergent validity nilai loading factornya harus $>0.70$. Sedangkan untuk discriminant validity nilai korelasi cross loading dengan peubah latennya harus lebih besar dibandingkan dengan korelasi terhadap peubah laten lainnya. Nilai $A V E$ harus lebih besar dari 0,50 dan nilai composite reliability harus $\geq 0.70$ (Hair et al., 2011).

Inner model atau model struktural menguji pengaruh antara satu peubah laten dengan peubah laten lainnya baik eksogen maupun endogen (koefisien parameter) atau menguji hipotesis dengan melihat $\mathrm{R}^{2}$ (koefisien determinasi) untuk peubah laten dependen yang mendapat pengaruh peubah laten independen dengan menggunakan ukuran stone-geisser $Q$ Square test dan melihat besarnya koefisien jalur strukturalnya. Stabilitas dari estimasi ini diuji dengan menggunakan uji t-statistik melalui prosedur bootstrapping. Hasil $\mathrm{R}^{2}$ sebesar 0,$67 ; 0,33 ;$ dan 0,19 mengindikasikan bahwa model "Baik", "Moderat", dan "Lemah" dan t-statistik harus $>1,96$ pada level 0,05 (Wiyono 2011).

\section{HASIL PENELITIAN DAN PEMBAHASAN}

\section{Validitas dan Reliabilitas}

Hasil uji validitas dan reliabilitas menunjukkan bahwa semua peubah valid dan semua peubah reliable. Tabel 1 menunjukkan bahwa semua indicator loadings berada di atas 0,70 dan $A V E$ untuk semua konstruk di atas 0,50, sehingga dapat disimpulkan bahwa semua peubah adalah valid. Tabel 1 juga menunjukkan bahwa Cronbachs Alpha dari semua peubah berada di atas 0,60 dan Composite Reliability di atas 0,60 sehingga hal tersebut menunjukkan semua peubah reliabel. 
Tabel 1

Uji Indikator

\begin{tabular}{|c|c|c|c|}
\hline Variables \& Items & Loading & Cronbachs Alpha & \\
\hline Atmospheric & & 0,907 & Composite \\
\hline Atmospheric 1 & 0,932 & & Reliability $=0,941$ \\
\hline Atmospheric 2 & 0,907 & & $\mathrm{AVE}=0,842604$ \\
\hline Atmospheric 3 & 0,915 & & \\
\hline Service Quality & & 0,805 & Composite \\
\hline Service Quality 1 & 0,784 & & Reliability $=0,886$ \\
\hline Service Quality 2 & 0,892 & & $\mathrm{AVE}=0,721$ \\
\hline Service Quality 3 & 0,867 & & \\
\hline Perceived Value & & 0,860 & Composite \\
\hline Perceived Value 1 & 0,904 & & Reliability $=0,914$ \\
\hline Perceived Value 2 & 0,912 & & $\mathrm{AVE}=0,781$ \\
\hline Perceived Value 3 & 0,83 & & \\
\hline Food Quality & & 0,853 & Composite \\
\hline Food Quality 1 & 0,888 & & Reliability $=0,901$ \\
\hline Food Quality 2 & 0,742 & & $\mathrm{AVE}=0,695$ \\
\hline Food Quality 3 & 0,898 & & \\
\hline Food Quality 4 & 0,797 & & \\
\hline Customer Satisfaction & & 0,913 & Composite \\
\hline Customer Satisfaction 1 & 0,897 & & Reliability $=0,939$ \\
\hline Customer Satisfaction 2 & 0,928 & & $\mathrm{AVE}=0,795$ \\
\hline Customer Satisfaction 3 & 0,896 & & \\
\hline Customer Satisfaction 4 & 0,843 & & \\
\hline Behavioral Intentions & & 0,885 & Composite \\
\hline Behavioral Intentions 1 & 0,888 & & Reliability $=0,928$ \\
\hline Behavioral Intentions 2 & 0,930 & & $\mathrm{AVE}=0,812$ \\
\hline Behavioral Intentions 3 & 0,886 & & \\
\hline
\end{tabular}

\section{Uji Hipotesis}

Kecuali $\mathrm{H} 4$ dan $\mathrm{H} 7$, semua hipotesis terbukti karena $\mathrm{t}>1,96$ pada tingkat signifikan 0,05 (lihat Tabel 2). Pengaruh atmosferik terhadap kualitas layanan (H1) terbukti positif dan signifikan karena $t=5,70>1,96$ pada tingkat signifikan 0,05 . Pengaruh atmosferik terhadap kualitas makanan (H2) terbukti positif dan signifikan karena $\mathrm{t}=5,84>1,96$ pada tingkat signifikan 0,05. Pengaruh atmosferik terhadap nilai yang dirasakan atau harga $(\mathrm{H} 3)$ terbukti positif dan signifikan karena $\mathrm{t}=3,17$ $>1,96$ pada tingkat signifikan 0,05. Pengaruh nilai yang dirasakan atau harga terhadap kepuasan pelanggan (H5) terbukti positif dan signifikan karena $t=9,06$ $>1,96$ pada tingkat signifikan 0,05. Pengaruh kualitas makanan terhadap kepuasan pelanggan (H6) terbukti positif dan signifikan karena $t=7,1884>1,96$ pada tingkat signifikan 0.05. Pengaruh kepuasan pelanggan terhadap niatan perilaku konsumen (H8) terbukti positif dan signifikan karena $t=12,59>1,96$ pada tingkat signifikan 0,05. Pengaruh kualitas makanan terhadap niatan perilaku konsumen (H9) terbukti positif dan signifikan karena $\mathrm{t}=6,43>1,96$ pada tingkat signifikan 0,05 . Hipotesis keempat tidak terbukti karena walaupun pengaruh kualitas layanan terhadap kepuasan pelanggan positif, namun tidak signifikan. Hal tersebut ditunjukkan oleh $\mathrm{t}$ $=1,41<1,96$ pada tingkat signifikan 0,05 . Hipotesis ketujuh juga tidak terbukti 
karena walaupun pengaruh kualitas layanan terhadap niatan perilaku konsumen juga positif, namun tidak signifikan yang ditunjukkan oleh $\mathrm{t}=1,60<1,96$ pada tingkat signifikan 0,05. Tidak terbukti signifikannya hipotesis empat dan tujuh bisa jadi disebabkan oleh karena di restoran " $X$ " konsumen tidak terlalu membutuhkan layanan, konsumen memilih dan mengambil sendiri bahan-bahan mentah dari tempatnya dan kemudian membawa ke meja saji dan memasak sendiri bahan-bahan tersebut pada tungku pembakaran yang telah tersedia di meja saji. Jadi konsumen lebih banyak melayani diri sendiri dari pada dilayani oleh pihak layanan restoran. Itulah sebabnya kualitas layanan walaupun berpengaruh positif terhadap kepuasan pelanggan dan niatan perilaku konsumen, namun tidak signifikan. Jadi konsumen menjadi puas dan berminat untuk datang kembali bukan oleh karena kualitas layanannya, namun lebih disebabkan oleh karena kualitas makanan dan harganya.

Tabel 2

T-Statistik

\begin{tabular}{lll}
\hline & & T Statistics \\
\hline Atmospheric & -> Behavioral Intentions & 5,278 \\
Atmospheric & -> Customer Satisfaction & 5,169 \\
Atmospheric & -> Food Quality & 5,843 \\
Atmospheric & -> Perceived Value & 3,168 \\
Atmospheric & -> Service Quality & 5,701 \\
Customer Satisfaction & -> Behavioral Intentions & 12,595 \\
Food Quality & -> Behavioral Intentions & 6,432 \\
Food Quality & -> Customer Satisfaction & 7,183 \\
Perceived Value & -> Behavioral Intentions & 7,456 \\
Perceived Value & ->Customer Satisfaction & 9,059 \\
Service Quality & -> Behavioral Intentions & 1,604 \\
Service Quality & -> Customer Satisfaction & 1,412 \\
\hline
\end{tabular}

\section{Multiple Mediating Effects Analysis}

Koefisien determinasi, $\mathrm{R}^{2}$ untuk variabel endogen kepuasan pelanggan sebesar 0,629. Ini berarti bahwa tiga peubah laten (kualitas layanan, nilai yang dirasakan, dan kualitas makanan) secara moderat menjelaskan $63 \%$ dari varian dalam kepuasan pelanggan. Kemudian koefisien determinasi, $\mathrm{R}^{2}$ untuk peubah endogen niatan perilaku konsumen sebesar 0,678. Ini berarti bahwa dua peubah laten (kualitas layanan dan kualitas makanan) secara bersama-sama menjelaskan dengan baik $68 \%$ varian dari niatan perilaku konsumen.

Tabel 3 menunjukkan pengaruh langsung atmosferik terhadap kualitas layanan sebesar 40\%; pengaruh langsung atmosferik terhadap kualitas makanan sebesar 40\%; pengaruh langsung atmosferik terhadap nilai yang dirasakan atau harga sebesar 24\%. Sedangkan, pengaruh langsung kualitas layanan terhadap kepuasan pelanggan sebesar $8 \%$; pengaruh langsung nilai yang dirasakan terhadap kepuasan pelanggan sebesar $44 \%$. Pengaruh langsung kualitas makanan terhadap kepuasan pelanggan sebesar $42 \%$ dan pengaruh langsung kualitas layanan terhadap niatan perilaku konsumen sebesar 7\%. Untuk pengaruh langsung kepuasan 
pelanggan terhadap niatan perilaku konsumen sebesar 69\%; dan pengaruh langsung kualitas makanan terhadap niatan perilaku konsumen sebesar 13\%. Tabel 3 juga menunjukkan pengaruh tidak langsung atmosferik terhadap niatan perilaku konsumen sebesar 29\%; dan pengaruh tidak langsung atmosferik terhadap kepuasan pelanggan sebesar $31 \%$.

Table 3

Koefisien Jalur

\begin{tabular}{lll}
\hline & & \\
\hline Atmospheric & -> Behavioral Intentions & $\beta$ value \\
Atmospheric & -> Customer Satisfaction & 0,291 \\
Atmospheric & -> Food Quality & 0,308 \\
Atmospheric & -> Perceived Value & 0,406 \\
Atmospheric & -> Service Quality & 0,240 \\
Customer Satisfaction & -> Behavioral Intentions & 0,398 \\
Food Quality & -> Behavioral Intentions & 0,691 \\
Food Quality & ->Customer Satisfaction & 0,416 \\
Perceived Value & -> Behavioral Intentions & 0,422 \\
Perceived Value & ->Customer Satisfaction & 0,304 \\
Service Quality & -> Behavioral Intentions & 0,439 \\
Service Quality & $->$ Customer Satisfaction & 0,122 \\
\hline
\end{tabular}

\section{PEMBAHASAN}

Temuan ini mendukung temuan penelitian Ha dan Jang (2012) bahwa persepsi atmosferik memiliki pengaruh positif dan signifikan terhadap kualitas layanan, kualitas makanan, dan niatan perilaku konsumen. Temuan ini juga mendukung temuan Ha dan Jang (2012) bahwa kualitas makanan berpengaruh positif dan signifikan terhadap niatan perilaku konsumen. Namun temuan penelitian ini tidak mendukung Ha dan Jang (2012) yang menemukan bahwa kualitas layanan berpengaruh signifikan terhadap niatan perilaku konsumen. Konsumen dari restoran "X" menghubungkan kualitas layanan dan kualitas makanan dengan persepsi mereka terhadap atmosferik restoran, yang mana hal tersebut kemudian mendorong mereka untuk ingin kembali menikmati layanan dan makanannya. Dengan demikian penelitian ini menunjukkan bahwa atmosferik merupakan faktor yang sangat penting dan perlu mendapat perhatian dari setiap pelaku usaha, khususnya sektor jasa boga.

Desain eksterior dan interior retail atau restoran akan memberikan dampak pada perasaan para konsumennya dan dapat menciptakan atau mempertahankan pengalaman kunjungan yang positif. Sebagaimana dikatakan oleh Donovan dan Rossiter (1982) bahwa pengalaman berbelanja atau kunjungan yang menyenangkan biasanya dipengaruhi oleh suasana lingkungan atau atmosferik dan hal tersebut dapat mendorong para konsumen untuk lebih tertarik membelanjakan uang mereka di sana. Orang-orang dari berbagai budaya yang berbeda memiliki gagasan yang berbeda juga tentang warna, wewangian (pengharum ruangan) dan suara atau music (Kotler 1973). Ketika konsumen berkunjung dan makan di restoring " $X$ ", mereka akan langsung disambut dengan warna-warna dekorasi ala Jepang dan disambut pelayanan 
yang mengenakan kimono, pakaian khas Jepang. Lingkungan atmosferik tersebut akan segera menciptakan kesan pada konsumen dengan menghubungkannya dengan kualitas dan nilai unggul dari bangsa Jepang.

Temuan ini mendukung temuan penelitian Qin dan Prybutok (2008) untuk restoran siap saji (fast food restaurants) di Amerika Serikat yang menemukan bahwa kualitas makanan tidak berpengaruh positif dan signifikan terhadap kepuasan pelanggan dan kepuasan pelanggan berpengaruh positif dan signifikan terhadap niatan perilaku konsumen. Temuan ini memiliki kesamaan dengan temuan Qin dan Prybutok (2008) bahwa kualitas layanan tidak berpengaruh signifikan terhadap kepuasan pelanggan. Temuan ini juga mendukung temuan penelitian Wen et al. (2012) yang dilakukan pada konsumen Amerika dan China di restoran siap saji bahwa kualitas makanan dan persepsi nilai memiliki pengaruh signifikan kepuasan pelanggan dan kepuasan pelanggan berpengaruh signifikan terhadap niatan perilaku konsumen. Walaupun pada umumnya kualias layanan memiliki peran penting dalam menjamin kepuasan dan kesetiaan pelanggan bisnis jasa seperti restoran, namun dalam penelitian ini menunjukkan hal sebaliknya. Konsumen restoran " $X$ " menunjukkan kepuasan dan loyalitas mereka yang tidak dipengaruhi oleh kualitas layanan yang mereka rasakan. Kepuasan mereka lebih dipengaruhi oleh atmosferik, kualitas makanan dan nilai yang dirasakan. Hal tersebut dapat difahami karena restoran " $X$ " menciptakan suasana di mana para konsumen dapat melayani diri sendiri. Pelanggan mengambil bahan-bahan mentah pada tempat yang tersedia, membawa bahan-bahan mentah tersebut ke meja mereka, lalu mereka mulai memanggang bahan-bahan makanan tersebut pada tungku pemanggang di meja mereka sendiri. Kebutuhan mereka untuk dilayani secara langsung oleh pelayanan restoran sangat sedikit. Itulah sebabnya kualitas makanan dan nilai yang dirasakan yang didukung oleh atmosferik yang lebih kuat mempengaruhi kepuasan dan kesetiaan mereka daripada kualitas layanan.

\section{SIMPULAN, KETERBATASAN DAN SARAN}

\section{Simpulan}

Berdasarkan hasil penelitian di atas maka untuk menciptakan kepuasan pelanggan dan niatan perilaku konsumen untuk setia pada perusahaan, restoran perlu meningkatkan kualitas layanan, kualitas makanan dan nilai yang dirasakan pelanggan. Atmosferik juga merupakan faktor penting yang patut diperhatikan karena hasil penelitian ini menunjukkan kualitas layanan, kualitas makanan dan nilai yang dirasakan dipengaruhi oleh atmosferik restoran. Jadi untuk menciptakan persepsi kualitas layanan yang baik di mata konsumen restoran " $X$ " perlu meningkatkan persepsi atmosferiknya. Demikian juga untuk menciptakan persepsi kualitas makanan di mata konsumen dan untuk menciptakan nilai yang dirasakan bahwa uang yang dikeluarkan konsumen untuk membayar harga dipandang setara 
dengan apa yang diperolehnya. Untuk menciptakan kepuasan pelanggan restoran " $\mathrm{X}$ " juga perlu meningkatkan nilai yang dirasakan sehingga konsumen merasa bahwa uang yang dikeluarkan untuk membeli produk dan layanan setara dengan apa yang didapatkan dan puas. Untuk menciptakan kepuasan pelanggan tersebut restoran juga perlu meningkatkan kualitas makanannya. Untuk menciptakan niatan perilaku konsumen atau untuk membuat pelanggan setia dan merekomendasikan produk atau jasa, restoran perlu meningkatkan usaha untuk membuat pelanggan menjadi puas. Restoran juga perlu meningkatkan kualitas makanan. Restoran juga perlu memperhatikan bahwa secara tidak langsung atmosferik juga dapat menciptakan kepuasan pelanggan dan loyalitas pelanggan atau niatan perilaku konsumen.

\section{Keterbatasan dan Saran}

Berikut beberapa keterbatasan penelitian ini: Pertama, penelitian ini hanya dilakukan di wilayah Jakarta dan pengambilan sampel tidak langsung dilakukan di restoran karena pihak restoran tidak memberikan ijin dengan alasan tidak ingin mengganggu kenyamanan pelanggan mereka. Kedua, penelitian ini menerapkan teknik convenience sampling, yaitu meminta konsumen yang mengaku pernah dan sering makan di restoran " $X$ ". Oleh sebab itu saran untuk penelitian yang akan datang adalah perlu mengambil sampel yang lebih besar, bukan hanya di wilayah Jakarta, namun ke wilayah-wilayah lain juga. Penelitian yang akan datang juga disarankan untuk melakukan pendekatan dengan para pengelola restoran untuk dapat membagikan kuesioner di tempat guna menghindari bias responden.

\section{DAFTAR PUSTAKA}

Ahtola, Olli T. 1985. "Price as a 'give' component in an exchange theoretic multicomponent model." In Association for Consumer Research, diedit oleh Thomas C. Kinnear, 623-26.

Babin, Barry J., dan Jill S. Attaway. 2000. "Atmospheric affect as a tool for creating value and gaining share of customer." Journal of Business Research 49 (2): 91-99. https://doi.org/10.1016/S0148-2963(99)00011-9.

Baker, Julie, Michael Levy, dan Dhruv Grewal. 1992. "An experimental approach to making retail store environment decisions." Journal of Retailing 68 (4): 44560.

Baker, Julie, A. Parasuraman, Dhruv Grewal, dan Glenn B. Voss. 2002. "The influence of multiple store environment cues on perceived merchandise value and patronage intentions." Journal of Marketing 66 (1): 120-41. https://doi.org/10.1509/jmkg.66.2.120.18470.

Chen, Han Shen, dan Tsuifang Hsieh. 2011. "The effect of atmosphere on customer perceptions and customer behavior responses in chain store supermarkets." African Journal of Business Management 5 (24): 10054-66. 
https://doi.org/10.5897/AJBM10.608.

Choi, Eun Jung, dan Soo-hyun Kim. 2013. "The study of the impact of perceived quality and value of social enterprises on customer satisfaction and repurchase intention." International Journal of Smart Home 7 (1): 239-51.

Cronin, J.Joseph, Michael K Brady, dan G.Tomas M Hult. 2000. “Assessing the effects of quality, value, and customer satisfaction on consumer behavioral intentions in service environments." Journal of Retailing 76 (2): 193-218. https://doi.org/10.1016/S0022-4359(00)00028-2.

Donovan, Robert J., dan John R. Rossiter. 1982. "Store atmosphere: an environmental psychology approach.” Journal of Retailing 58 (1): 34-37.

Ehigie, Benjamin Osayawe. 2006. "Correlates of customer loyalty to their bank: A case study in Nigeria." International Journal of Bank Marketing 24 (7): 494508. https://doi.org/10.1108/02652320610712102.

Ferree, Marie. 1973. "What is food quality?" Journal of Food Distribution Research 4 (2): 34-36.

Gilbert, G. Ronald, Cleopatra Veloutsou, Mark M.H. Goode, dan Luiz Moutinho. 2006. "Measuring customer satisfaction in the fast food industry: A crossnational approach." The Journal of Services Marketing 18 (5): 371-83. https://doi.org/10.1108/08876040410548294.

Ha, Jooyeon, dan Soo Cheong Jang. 2012. "The effects of dining atmospherics on behavioral intentions through quality perception." Journal of Services Marketing 26 (3): 204-15. https://doi.org/10.1108/08876041211224004.

Hair, Joe F., Christian M. Ringle, dan Marko Sarstedt. 2011. "PLS-SEM: Indeed a Silver Bullet." The Journal of Marketing Theory and Practice 19 (2): 139-51. https://doi.org/10.2753/MTP1069-6679190202.

Kobylanski, Andrzej, dan Bozena Pawlowska. 2012. "Managing customer satisfaction: A conceptual framework." The Business Review, Cambridge 20 (1): $33-34$.

Kotler, Philip. 1973. "Atmospherics as a Marketing Tool.” Journal of Retailing 49 (4): 46-64. https://doi.org/10.1016/j.obhdp.2011.03.002.

Monroe, Kent B. 2002. Making profitable decisions (3rd Ed.). New York: McGrawHill Book Company.

Olorunniwo, Festus, Maxwell K. Hsu, dan Godwin J. Udo. 2006. "Service quality, customer satisfaction, and behavioral intentions in the service factory." The $\begin{array}{lllll}\text { Journal of } & \text { Services } & \text { Marketing } & 20 & \text { (1): }\end{array}$ https://doi.org/10.1108/08876040610646581.

Parasuraman, A., A. V. Zeithaml, dan L. L. Berry. 1988. "SERVQUAL: A multiple- 
item scale for measuring consumer perceptions of service quality." Journal of Retailing 64 (1): 12-40.

Patterson, Paul G., Lester W. Johnson, dan Richard A. Spreng. 1997. "Modeling the determinants of customer satisfaction for business-to-business professional services." Journal of the Academy of Marketing Science 25 (1): 4-17. https://doi.org/10.1007/BF02894505.

Polyorat, Kawpong, Suvenus Sophonsiri, Polyrat Kawpong, dan Suvenus Sophonsiri. 2010. "The influence of service quality dimensions on customer satisfaction and customer loyalty in the chain restaurant context: a thai case." Journal of Global Business and Technology 6 (64): 64-76.

Purwanto, Edi. 2014. "The effect of consumer ethnocentrism on perceived domestic product quality and purchase intentions among young consumers in Jakarta, Indonesia.” International Journal of Asian Social Science 4 (9): 1003-12.

Qin, G, dan Victor R. Prybutok. 2008. "Determinants of customer-perceived service quality in fast-food restaurants and their relationship to customer satisfaction and behavioral intentions." The Quality Management Journal 15 (2): 35-50. https://doi.org/10.1080/10686967.2008.11918065.

Ryu, Kisang, dan Soocheong Jang. 2008. "Influence of restaurant's physical environments on emotion and behavioral intention." Service Industries Journal 28 (8): 1151-65. https://doi.org/10.1080/02642060802188023.

Siddiqi, Kazi Omar. 2011. "Interrelations between service quality attributes, customer satisfaction and customer loyalty in the retail banking sector in Bangladesh." International Journal of Business and Management 6 (3): 1236.

Szymanski, David M., dan David H. Henard. 2001. "Customer satisfaction: A metaanalysis of the empirical evidence." Journal of the Academy of Marketing Science 29 (1): 16-35. https://doi.org/10.1177/0092070301291002.

Tjiptono, Fandy, dan Gregorius Chandra. 2011. Service, quality \& satisfaction. Yogyakarta: Andi.

Wen, Chao, Hong Qin, Victor Prybutok, dan Charles Blankson. 2012. "The role of national culture on relationships between customers ' perception of quality, values, satisfaction and behavioral intentions." The Quality Management Journal 19 (4): 7-23.

Wiyono, Gendro. 2011. Merancang penelitian bisnis dengan alat analisis SPSS 17.0 \& SmartPLS 2.0. Yogyakarta: Unit Penerbit dan Percetakan STIM YKPN.

Zeithaml, Valarie A. 1988. "Consumer perceptions of price, quality, and value: A means-end model and synthesis of evidence." The Journal of Marketing 52 (3): 2-22. https://doi.org/10.2307/1251446. 
Zeithaml, Valarie a., Leonand L. Berry, dan A. Parasuraman. 1996. "The behavioral consequences of service quality." Journal of Marketing 60 (2): 31-46. https://doi.org/10.2307/1251929. 